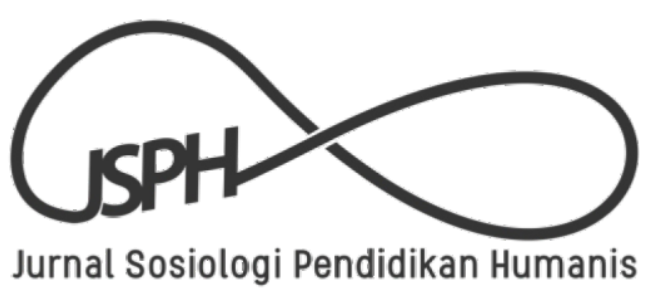

\title{
MASJID DAN AMBIVALENSI DEMOKRASI \\ (STUDI KRITIS PADA MASJID JOGOKARIYAN MANTRIJERON, YOGYAKARTA)
}

\author{
Ika Silviana \\ Program Studi Sosiologi Agama, STAIN Kediri \\ Email:veana_ieka@yahoo.com
}

\begin{abstract}
Abstrak
Ruang publik menjadi salah satu media komunikasi aktif antar masyarakat publik dengan tujuan mengkoordinir permasalahan sosial yang berdasar pada nalar publik. Melalui gerakan kaum muslim di Mantrijeron Yogyakarta, Masjid Jogokariyan melaksanakan fungsinya sebagai ruang publik dengan melahirkan kegitan-kegiatan yang menjawab permasalahan sosial masyarakat. Pronsip dasar dari gerakan ini adalah humanisme Islam yang selaras dengan nilai-nilai ideal dari konsep ruang publik ideal Jürgen Habermas. Pemanfaatan ruang publik dengan mendasarkan pada demokrasi deliberatif dapat berimplikasi positif terhadap kesejahteraan masyarakat. Disisi lain praktik yang dilakukan oleh masjid Jogokariyan menyeret masyarkat publik untuk bersifat konsumtif dan dependen terhadap peran para aktor (takmir). Dengan demikian perlu pengawalan secara terus menerus untuk menciptakan ruang publik deliberatif, tentu melalui komunikasi yang efektif.
\end{abstract}

Kata Kunci : Masjid, Ruang Publik, Demokrasi Deliberatif, Sublimasi Umat

\section{MASJID AND AMBIVALENCE OF DEMOCRATISM \\ (CRITICAL STUDY OF JOGOKARIYAN MASJID MANTIREJON YOGYAKARTA )}

\begin{abstract}
Public sphere becomes a medium of public active communication aims to coordinating the social problems based on public reason. Through the movement of the Muslims in Mantrijeron Yogyakarta, Masjid Jogokariyan perform its function as a public sphere with some activities as a response of social problem. Principles this movement is the humanism of Islam that is in harmony with concept of ideal public sphere by Jürgen Habermas. Utilization of public sphere by basing on deliberative democracy may have positive implications for the welfare of society. On the other hand practices carried out by the Jogokariyan mosque dragging the public to consumptive and dependent on the actors (takmir). Therefore need the escort continuously to create a public sphere that is deliberative, certainly through effective communication.
\end{abstract}

Keywords : Mosque, Public Sphere, deliberative democracy, Sublimation 


\section{PENDAHULUAN}

Masjid merupakan salah satu simbol sakral bagi kaum muslim yang berfungsi sebagai tempat terlaksananya segala bentuk kegiatan religius. Aktivitas-aktivitas teologis yang dilakukan di masjid menjadi sarana untuk menghidupkan masjid, yakni menjadi salah satu penopang meningkatkan kualitas keimanan umat muslim. Sebagai ruang yang sakral tentu kehormatan masjid sangat dijaga, sehingga pengawasan terhadap orang-orang yang mendatangi masjid menjadi prioritas utama. Pun dengan kegiatan-kegiatan yang akan diselenggarakan di masjid. Seiring perkembangan zaman fungsi religius masjid kian berdampingan dengan fungsi sosialnya. Masjid tidak lagi hanya sebagai tempat untuk beribadah tetapi juga menjadi tempat untuk meningkatkan kesejahteraan umat serta membantu menyelesaikan permasalahan di masyarakat.

Permasalahan sosial tidak datang secara tiba-tiba, melainkan ditebarkan melalui tangan-tangan kapitalis. Anak kandung modernisasi ini memberikan ekses yang mengusik kehidupan masyarakat, baik secara materi maupun psikis. Modernitas yang begitu naif memberikan pilihan sulit bagi masyarakat untuk bertindak, dan berlahan menggiring masyarakat pada jurang kemiskinan. Disini pemerintah terlampau sulit menangani permasalahan kemiskinan, karena terdapat kekeliruan dalam memandang orang miskin. Pemerintah melihat orang miskin sebagai orang yang tidak memiliki kemapuan untuk mengerjakan beberapa hal, sehingga memilih untuk menempuh kebijakan untuk memberi bantuan. Kebijakan inilah yang justru menjadi bentuk kegagalan pemerintah dan menjadikannya sebagai keadaan permanen (Prasetyo, 2005: 74). Untuk menyikapi kekosongan tindakan pengentasan kemiskinan, perlu adanya peran aktif dari sektor lain. Agama menjadi salah satu sektor yang memiliki pengaruh besar dalam tindakan kemanusiaan. Islam sendiri memaknai humanisme sebagai tindakan memanusiakan manusia sesuai dengan tugasnya sebagai khalifah Allah di atas bumi. Menurut Iqbal nilai-nilai humanisme Islam meliputi tiga hal pokok, yakni prinsip kebebasan (liberty), persaudaraan (fraternity), dan persamaan (equality). Ketiga prinsip tersebut merupakan inti ajaran Islam dengan intisari tauhid sebagai persamaan, solidaritas, dan kebebasan (Iqbal, 1971: 154). Dengan demikian, ummat islam memiliki keharusan untuk menjalankan perannya untuk lebih aktif dalam mencapai kesejahteraan umat.

Komersialisasi layanan publik dituding sebagai akar permasalahan kegagalan kebijakan-kebijakan pemerintah. Untuk menikmati layanan publik seperti sekolah atau rumah sakit masyarakat harus menyiapkan biaya yang tidak sedikit. Jika pun masyarakat ingin mengajukan keringan, perlu prosedur yang bertele-tele untuk memanfaatkan bantuan dari pemerintah. Tentu sebagai muslim perlu lebih sensistif dalam melihat permasalahan tersebut. Masjid yang juga merupakan ruang publik bagi umat muslim dapat berperan aktif untuk melakukan perubahan pada masyarakat. Peran aktif masjid sebagai wadah aktivitas religi dan sosial telah dibuktikan oleh masjid Jogokariyan, Yogyakarta. Masjid tersebut menunjukkan kemandirian dalam mengej- 
wantahkan nilai-nilai humanisme Islam. Dari sinilah bukti bahwa masjid menjadi ruang publik yang nyata berpotensi untuk menciptakan kemandirian masyarakat.

Praktik kemandirian masjid Jogokariyan tidak lepas dari organisasi yang dijalankan oleh takmir secara profesional. Peran takmir menjadi nahkoda untuk mengarungi permasalahan-permasalahan di masyarakat serta berupaya untuk menyajikan solusi-solusinya. Tak terbantahkan bahwa masjid Jogokariyan merupakan ejawantah ruang publik yang memberikan manfaat besar bagi perubahan kehidupan masyarakat. Melalui artikel ini kajian tentang masjid Jogokariyan ditelisik melalui praktik-praktik kegiatannya dan melihat posisi masyarakat dalam pelaksanaannya. Sebagai subyek aktif apakah masyarakat sudah bersikap demokratis?

\section{METODE PENELITIAN}

Studi ini dilakukan dengan metode kualitatif melalui pendekatan deskriptif terhadap praktik ruang publik berbasis masjid. Pendekatan deskriptif ini digunakan untuk menjelaskan peran masjid dalam merespon permasalahan sosial dengan mendasarkan tindakan pada kepentingan publik, yakni masyarakat di sekitar masjid Jogokariyan, Mantrijeron Yogyakarta. Pengumpulan data dilakukan melalui tiga cara, yakni interview, observasi dan doku-mentasi. Penentuan informan dilakukan dengan menggunakan purposive sampling berdasarkan pertimbangan kriteria sesuai dengan fokus penelitian, sehingga informan dititikberatkan pada masyarakat sektar masjid yang terlibat langsung dengan program-program di masjid Jogokariyan. Data yang diperoleh dianalisis dengan menggunakan pendekatan Miles dan Huberman yang dilakukan secara interaktif dan berlangsung secara terusmenerus hingga data jenuh dan mencapai refleksi atas hasil analisis.

\section{HASIL DAN PEMBAHASAN Mengenal Masjid Jogokariyan dan Praktik Partisipasinya}

Masjid Jogokariyan yang beralamatkan di jalan Jogokariyan No. 36 kampung Jogokariyan, kelurahan Mantrijeron, Kecamatan Mantrijeron, Kota Yogyakarta, provinsi Daerah Istimewa Yogyakarta ini memiliki daya tarik tersendiri bagi berbagai kalangan. Ditengarahi adanya banyak penelitian dan kajian tentang masjid fenomenal ini. Perkembangan pesat melalui program-program yang inovasinya menjadi magnet untuk menjadikannya sebagai acuan masjid yang melaksanakan fungsi masjid sebagaimanamestinya. Layakanya panutan umat Islam, Nabi Muhammad saw, menjadikan masjid sebagai wadah aktivitas umat, sekaligus sebagai sarana untuk mensejahterkan umat. Berawal dari nilai tersebut pendiri masjid Jogokariyan, Muhammad Jazir, berupaya membangun masjid yang bermanfaat bagi masyarakat sekitar, baik secara spiritual maupun sosial.

Merunut dari sejarahnya, masjid Jogokariyan didirkan sebagai respon situasi politik keagamaan pasca G30 S/ PKI. Secara sosiokultural sebagian besar masyarakat kampung Jogokariyan adalah abangan. Para perintisnya merupakan mahasiswa dari IAIN Sunan Kalijaga yang disokong oleh para pengusaha batik yang mempunyai tanah di kampung Jogokariyan. Kekuatan ekonomi 
masyarakat pada masa itu mendorong untuk berinisiatif membeli sebidang tanah untuk membangun masjid. Perjuangan dari enam mahasiswa IAIN Sunan Kalijaga dilandasi dengan pendekatan pendekatan kesejahteraan. Sejak awal masjid berdiri, memfokuskan masjid sebagai solusi persoalanpersoalan masyarakat, terutama masalah ekonomi. Mengingat saat itu merupakan pasca peristiwa G30 S/ PKI, banyak kepala keluarga yang menjadi tahanan politik, kondisi ekonomi tidak menentu, beras susah, kehidupan susah, maka masjid ini hadir sebagai salah satu solusi bagi kehidupan masyarakat, yakni menggerakan PKO (Penolong kesengsaraan Oemoem), mulai dari penyantunan fakir miskin dengan kebutuhan hidup, hingga permasalahan pendidikan. Jadi, sebagian besar muridnya adalah anak-anak yang orang tuanya menjadi korban revolusi.

Pembangunan masjid dilakukan pada tahun 1966. Para pionir secara simultan mengupayakan perkembangan masjid Jogokariyan. Masjid ini dapat diterima baik oleh masyarakat dan hingga kini mendapatkan kepercayaan dari masyarakat bukan dilakukan dengan cara yang mudah, tetapi perlu ketelatenan untuk melakukan akulturasi antara agama Islam dengan kebudayaan Jawa yang dulunya mayoritas beragama HinduBudha. Proses ini berlangsung dengan baik, hingga di tahun 2014 terdapat lebih/ kurang 3.970 jiwa dapat mengakses dan terlibat pada kegiatan di masjid Jogokariyan. Dari angka tersebut terdapat $280 \mathrm{KK}$ miskin dan 68 anak yatim. Kemiskinan masyarakat semakin menjadi kektika para pengusaha batik mengalami kebangkrutan dan banyak masyarkat terjerat hutang-piutang. Disinilah andil masjid dalam mengetaskan masyarakat dari keterpurukan dan berupaya membangun kembali kesejahteraan masyarakat. Pengelolan masjid dilakukan oleh takmir yang melibatkan anak kelas VIII SMP hingga kalangan professional. Upaya ini dilakukan untuk melakukan regenerasi serta memberikan porsi yang tepat bagi kebutuhan kegiatan masjid, sehingga perlu melibatkan masyarakat dari segala umur. Adapun biribiro yang telah dirintis oleh takmur di masjid Jogokariyan diantaranya adalah:

1. Biro pembinaan HAMAS (Himpunan Anak-anak Masjid Jogokariyan)

2. Biro KAUM (Komite Aksi Untuk Umat)

3. Biro olah raga

4. Biro Pembinaan RMJ (Remaja Masjid Jogokariyan)

5. Biro pembinaan kader mubaligh

6. Biro teknologi Informasi

7. Biro pembinaan KURMA (Alumni Remaja Masjid Jogokariyan dan Bapak Muda)

8. Biro pengajian ahad legi

9. Biro keamanan

10. Biro pembinaan UMIDA (Ibu-ibu muda)

11. Biro FKMS (Forum kajian malam selasa)

12. Biro dokumentasi dan kearsipan

13. Biro pembinaan ibadah haji

14. Biro IKS (Ikatan Keluarga Sakinah)

15. Biro kerumahtanggaan

16. Biro ibadah jumat

17. Biro pembinaan perpustakaan

18. Biro seni dan budaya

19. Biro pembinaan kewirausahaan 
20. Biro humas dan penerbitan (tim jurnalistik)

21. Biro bimbingan al-qur'an

22. Biro imam dan muadzin

23. Biro koordinator jama'ah

24. Biro zakat

25. Biro perawatan jenazah

26. Biro poliklinik

27. Biro kuliah subuh

28. Biro pemberdayaan perempuan

29. Biro golongan darah

Masing-masing biro di atas memiliki program kerja yang secara langsung melibatkan masyarakat umum. Dengan melihat data di atas kegiatan yang cetuskan oleh masjid sudah menyentuh berbagai lini kehidupan masyarakat, sehingga dapat dikatakan bahwa kebutuhan dari masyarkat Matrijeron telah terwadahi. Menejemen Masjid merupakan suatu proses pencapaian tujuan melalui diri sendiri dan orang lain (internal takmir). Di dalamnya terkandung proses ketauladanan dan kepemimpinan yang melibatkan semua potensi umat dalam membina kehidupan masyarakat (eksternal) melalui optimalisasi fungsi dan peran masjid berdasarkan nilai-nilai Islam (Suherman, 2012:26).

Tanggung jawab sosial yang dilaksanakan oleh masjid Jogokariyan meliputi berbagai bidang. Adapun praktik peran masjid di bidang kesehatan adalah memberikan fasilitas pengobatan murah melalui poliklinik. Sejak dibangunnya klinik permanen di serambi timur masjid, masyarakat dapat berobat dengan harga murah bahkan gratis di klinik tersebut. Klinik buka pada akhir minggu, mulai Jumat siang hingga Minggu. Jadwal tersebut menyesuai- kan dengan jadwal dokter yang bertugas. Bagi masyarakat yang memiliki kartu orange yang menandakan mereka sering shalat subuh berjama'ah, mendapat pelayanan pengobatan gratis.

Sedangkan dibidang ekonomi dan pendidikan dilakukan dengan memberikan kemudahan dalam peminjaman modal usaha dan pengentasan jeratan rentenir. Pada periode Jogokariyan Darussalam II diadakan program peminjaman modal oleh masjid Jogokariyan. Program peminjaman modal juga disertai dengan pengentasan wargawarga yang terjebak oleh rentenir. Peminjaman modal oleh takmir masjid Jogokariyan tanpa dikenakan bunga, sehingga membantu masyarakat. Selain itu masjid memberikan kelonggaran bagi masyarakat yang mengalami kebangkrutan usaha untuk tidak mengembalikan modal yang telah dipinjam. Sedangkan untuk anak yatim dan dhuafa diberikan tunjangan dua kali dalam sebulan. Tunjangan tersebut berupa sembako, seragam sekolah, perlengkapan sekolah dan pembebasan SPP.

\section{Masjid Jogokariyan sebagai Ruang Demokratis dan Antisipasi Sublimasi Umat \\ Kehidupan manusia dihadapkan} pada realitas yang terfragmentasi dalam ruang-ruang. Terdapat distingsi antara ruang privat dan ruang publik. Tentu juga memiliki pengaruh pada tindakan yang harus di pilih dalam memposisikan diri pada ruang yang berbeda. Secara spontan dapat dilihat bahwa ruang privat dimaknai sebagai ruang yang hanya dimiliki oleh seseorang, tanpa ada campur tangan dari orang lain. Sedangkan ruang publik merupakan ruang yang 
mempertemukan antara individu satu dengan yang lainnya dan di dalamnya terdapat komunikasi yang saling mempengaruhi satu sama lain. Namun pada konteks ini akan meniti pada pemahaman ruang publik sesuai besutan Jürgen Habermas. Ruang publik yang dimaksud memainkan peran yang vital dalam penguatan demokrasi, yakni sebagai ruang yang dihidupi oleh masyarakat sipil dan berfungsi sebagai intermediari antara negara dengan individu privat (Prasetyo, 2012: 171).

Ada beberapa makna terkait ruang publik, akan tetapi ruang publik yang dimaksudkan dalam pembahasan ini adalah ruang publik tradisional dan ruang publik media. Bagaimana ruang publik sebagai yang tradisional dan yang berupa media? Pola ini dapat ditemui dalam satu bentuk, yakni masjid Jogokariyan Yogyakarta. Masjid ini merupakan suatu bentuk ruang tradisional yang menunjukkan sebagai tempat publik yang dimanfaatkan masyarakat untuk melakukan kegitan, baik kegitan-kegiatan religi maupun kegiatan sosial. Sebagai ruang publik tradisional masjid ini mampu menciptakan komunikasi aktif yang diwujudkan dalam keterlibatan berbagai pihak untuk melakukan suatau kegitan. Metode yang digunakan tidak menihilkan nalar publik dalam melihat suatu permasalahan sosial.

Seperti yang telah diulas sebelumnya bahwa permasalahan di bidang pendidikan dan kesehatan merupakan salah satu bentuk hak dari masyarakat dan bersifat publik. Permasalahan sosial yang ditimbulkan dari faktor tersebut berupa pelayanan publik yang kurang atau tidak memadai bagi masyarakat. Hak-hak inilah yang menjadi alasan perlunya ruang publik untuk menggelar proses negosiasi antara warga sipil dan negara. Sering kali negara hadir dalam porsi-porsi yang berjarak dengan kebutuhan masyarakat. Secara struktural pemerintah memlih para teknokrat untuk merumuskan suatu kebijakan untuk mengentaskan masyarakat dari permasalahannya. Namun celakanya, banyak ditemui bahwa pemerintah kurang memahani kondisi masyarakat secara spesifik.

Masyarakat masih saja mengalami kebingungan untuk bersandar kepada siapa. Keberadaan masjid Jogokariyan memberi kan nafas baru bagi masyarakat di kelurahan Mantrijeron, Kota Yogyakarta dan sekitarnya untuk merasakan kelegaan. Setidaknya masyarakat mengetahui dan menyadari bahwa terdapat ruang publik yang mampu mengkoordinir permasalahan sosial yang dirasakan. Selain melalui ruang publik tradisional, masjid Jogokariyan juga memanfaatkan ruang publik media. Diilhami dari perkembangan teknologi komunikasi, kehadiran internet semakin memuluskan tindakan aktif dari masyarakat muslim. Melalui website-nya, masjid Jogokariyan dapat melakukan koordinasi secara komprehensif dan secara transparan membuat paloran kegiatan serta keuangan masjid. Media ini sangat membantu dalam melakukan publikasi sekaligus koordinasi masyarakat sipil untuk melakukan tindakan nyata dalam meningkatkan kesejahteraan masyarakat, khususnya dalam mengentaskan masyarakat dari kemiskinannya dalam mengakses fasilitas publik.

Berdasarkan penelitian yang dilakukan oleh Bambang dan Anita, warga 
Yogyakarta merupakan warga yang memiliki dan menggunakan teknologi madia dengan prosentase yang tinggi. Disebutkan bahwa terdapat $75 \%$ memiliki internet, $96 \%$ memiliki telepon seluler (2011: 32). Melihat fungsi telepon seluler dalam konteks aktivitas diskusi ruang publik, yakni sebagai alat untuk menguatkan praktik jurnalisme warga serta mampu mempengaruhi pendefinisian berita, agenda berita, dan penyortiran berita. Data tersebut sangat mendukung langkah yang dilakukan pihak masjid Jogokariyan untuk memanfaatkan teknologi sebagai media komunikasi. Segala kegiatan dan informasi penting dapat disampaikan melalui media tersebut, sehingga masyarakat luas mampu mengawal bentuk demokrasi deliberatif masyarakat Mantrijeron khususnya. Hanya saja kali ini lebih meniti pada tindakan dari masyarakat sipil dalam upaya menyelesaikan permasalahan sosial, berbeda dari fokus yang dilakukan oleh Habermas pada kelompok borjuis dan bermuatan politik.

Modal komunikasi yang dipilih merupakan proyek atau suatu tugas untuk melakukan mobilisasi lairan komunikatif yang telah ada diantara praktik sosial. Salah satu inovasi dari takmir masjid untuk meningkatkan jumlah jamaah salat subuh, dibuatkan acara wedangan seusai salat. Ini menjadi salah satu bentuk ruang penjaring informasi dari masyarakat sipil. Menginggat budaya wedangan merupakan salah satu kekhasan masyarakat Yogyakarta, maka komunikasi di acara tersebut dapat memupuk komunikasi aktif anatara masyarakat sipil dengan takmir. Komunikasi aktif ini cenderung melibatkan warga kota untuk melakukan diskusi dengan warga lain sebagai bentuk menuntaskan hak dalam hal informasi dan akses untuk berpartisipasi (Carpentier, 2008). Penciptaan kontes demokratis ini tentu saja imperatif sebagai penyeimbang penciptaan tanggungjawab moralitas.

Selain dengan menarik masyarakat sipil untuk mendatangi masjid, takmir juga berperan aktif dalam tindakan-tindakan darurat seperti menjadi relawan yang tanggap bencana dengan mengirimkan tenaga-tenaga dengan skill yang mumpuni, dengan mengirim tenaga medis misalnya. Peran aktif tersebut diharapakan dapat dilakukan secara sustainable dan dapat memberikan potret bagi masjid-masjid yang lain sebagai ruang publik yang bermanfaat ganda, untuk memupuk keimanan dan solidaritas sosial.

Praktik yang dilakukan oleh masjid Jogokariyan telah mengejawantahkan tiga elemen penting yang merupakan unsur konstitutif dari ruang publik, yaitu orangorang privat/ individu warga negara, ruang diskusi, dan persoalan publik. Dimana masyarakat sipil berkumpul untuk melahirkan program-program yang cerdas dengan menggunakan masjid sebagai ruang untuk berdiskusi dan koordinasi serta berupaya untuk mengurai permasalahan sosial, terutama masalah pendidikan dan kesehatan. Pada ruang publik tradisional yang dilakukan dengan cara tatap muka memberikan sepirit perubahan yang luar biasa bagi masyarakat. Walaupun memiliki keterbatasan pada cakupan geografis. Namun hal ini ditunjang dengan pemanfaatan ruang publik media (internet) yang menghapus sekat-sekat geografis yang ada. 
Sesuai dengan prinsip manajemen masjid Jogokariyan mendasarkan pada nilainilai bahwa masjid menjadi jantung pokok kegiatan masyarakat dan bermanfaat bagi kesejahteraan masyarakat sekitar, kini telah nyata dirasakan. Masyarakat yang kurang mampu tidak lagi khawatir untuk mendapatkan pelayanan berobat gratis atau dengan biaya terjangkau hanya dengan rajin beribadah di masjid Jogokariyan. Pun dengan pendidikan bagi anak-anak kurang mampu dapat dilakukan dibawah bimbingan takmir yang mewadahi biro di bidang pendidikan. Pada pelaksanaannya tentu tidak lepas dari nilai-nilai humanisme Islam. Prinsip-prinsip itulah yang juga mendasari konsepnya tentang ruang publik ideal Habermas, yakni memiliki ideal-ideal normatif warisan Pencerahan yang secara implisit terkandung di dalamnya: kebebasan, solidaritas, persamaan (liberte, fraternite, egalite). Melalui interpretasi terhadap kebaikan umum (common good) yang pada akhirnya menjadi kriteria untuk menguji kemasukakalan dari klaim-klaim yang diajukan anggotanya dengan mendasar pada gagasan kebaikan umum ini (Prasetyo, 2012: 174)

Pihak-pihak yang terlibat dalam kegiatan masjid Jogokariyan dipertemukan dalam ruang publik dengan tanpa kepentinga pribadi, yakni berlandaskan pada kesamaan penggunaan rasio yang berkarakter kepentingan umum. Maka, setiap orang memiliki kesempatan yang sama untuk terlibat, karena yang menjadi fokus bukanlah status seseorang, melainkan nilai-nilai kebijaksanaan sebagai tujuan bersama.

Aktivitas yang bernafaskan religiusitas dan sosial-kemanusiaan sering kali berdampingan langsung dengan sektor lain, yakni pemerintah. Ruang publik ini menjadi wadah untuk melakukan koreksi terhadap kegagalan pemerintah dalam mengatasi permasalahan di masyarakat. Konstan kegiatan-kegiatan yang dirumuskan oleh aktor-aktor penting di masjid Jogokariyan yang berangkat sebagai warga sipil, Habermas menyebutnya sebagai otokhton, merupakan kritik tajam bagi pemerintah. Bahwa melalui solidaritas yang dibangun oleh kelompok publik (masjid), mengambil alih peran pemerintah dalam menciptakan kesejahteraan. Disini meniti pada sensistifitas dalam memahami kondisi masyarakat. Koreksi ini tidak serta-merta dapat dimaknai sebagai kemandirian masyarakat yang kemudian membuat pemerintah lepas tangan. Namun perlu adanya kesadaran bersama bahwa perlu adanya diskusi aktif yang lebih intens antara masyarakat dengan pemerintah, khususnya melalui ruang-ruang publik yang telah ada. Selain peran aktif dari para aktor juga melibatkan filantropis (dermawan) yang berpartisipasi dalam kegiatan sosial di masjid Jogokariyan. Kemunculan filantropis ini sebagai sebauh aktivitas sosial yang berbasis pada religiusitas maupun sosial merupakan aksi yang merespon terhadap problem kemiskinan di pedesaan (Soelaiman, 1998: 154). Hal ini merupkan respon aktif dari masyarakat lokal, baik di pendesaan maupun di lingkungan kota tidak menutup terciptanya aktivitas-aktivitas yang berdamai dengan struktur dan kultur yang ada. Masyarakat muslim (khususnya) mengejawantahkan konsep tauhid yang berimplikasi kepada upaya mewujudkan persamaan. Adanya 
persamaan itu akan menumbuhkan solidaritas atau persaudaraan. Selanjutnya, solidaritas menuntut pemberian kebebasan kepada manusia dalam hidupnya. Kebebasan inilah yang dimaksudkan hasil dari peranan masjid sebagai ruang demokratis.

Dari langkah progresif yang dilakukan oleh gerakan muslim perlu adanya refleksi secara mendalam. Kemampuan para aktor dalam mengkoordinasi masyarakat publik tidak dapat dilepaskan dari kuatnya arus kapitalisme yang kian berkembang. Tidak menutup kemungkinan proses kapitalisasi akan berlanjut pada sektor lain, yakni menjangkiti mentalitas masyarakat. Keberadaan amsjid yang mampu memenuhi kebutuhan masyarakat dikhawatirkan juga akan memupuk perkembangan masyarakat konsumen. Komunikasi aktif dari kelompok aktor (takmir) dapat direspon oleh masyarakat hanya dengan menikmati hasil dari tindakan tersebut. Hal inilah yang dipesankan oleh Habermas pada bentuk ruang publik borjuis yang dikajinya, bahwa rasa-kedirian kelas borjuis yang dulu ditempa melalui keahlian mengartikulasikan gagasan dan argumen bercorak publik kini menjadi luruh (Prasetyo, 2012: 175). Pada pelaksanaan kegiatan di masjid Jogokariyan masih banyak masyarakat yang memiliki kecenderungan dependen terhadap aktor masjid. Masyarakat merasa cukup dengan pelayanan masjid dan menajdi acuh pada kontrol atas kewajiban negara untuk memelihara warganya. Ditakutkan atmosfer ini menimbulkan regres pada pertumbuhan ruang publik, dan mengancam diskusi publik yang rasional menjadi kehilangan tempatnya dalam masyarakat secara keseluruhan.
Demokrasi deliberatif telah dipraktikkan dengan apik oleh takmir masjid sejak awal pembangunan masjid. Hingga kini kaderisasi terus dilakukan untuk menghidupkan ruang publik ini, namun latensi pada dependensi masyarakat maupun pemerintah tidak dapat dihindarkan. Kemandirian masjid justru berpotensi dalam terciptanya ambivalensi demokrasi deliberatif. Suara masyarakat sipil yang diharapkan dapat melakukan kontrol terhadap kualitas fasilitas publik dan produk kebijakan pemerintah tersublimasi dengan kehadiran masjid. Disini semakin terlihat jarak antara masyarakat sipil dengan pemerintah, dan menunjukkan keterbatasan dari masyarakat sipil (Habermas, 1996: 372). Batasan ini diperlukan bagi bekerjanya sistem demokrasi secara masuk akal. Dia dapat secara langsung mentransformasi dirinya, namun hanya dapat memberikan efek tidak langsung terhadap transformasi dari sistem politik.

\section{PENUTUP}

Kehadiran masjid Jogokariyan seyogyanya tetap memelihara diskursus dan komunikasi aktif dari masyarakat sipil, tidak hanya melibatkan masyarakat sebagai pelaksana program masjid. Jika dalam perkembangannya masyarakat sipil hanya menjadi konsumen atas program yang digalakkan oleh takmir masjid, ini menandakan bahwa adanya kemandekan komunikasi efektif masyarakat. Kapasitas masyarakat untuk melakukan kritik terhadap kebijakan pemerintah justru terhenti dengan rasa puas atas keberadaan masjid. Ada beberapa bentuk sublimasi yang ditemui 
pada masyarakat, pertama, masyarakat cenderung aktif dalam partisipasi eksekusi, melaksanakan program yang telah didesain oleh takmir masjid. Kedua, melemahnya kritik publik terhadap menurunnya fasilitas pada ruang publik yang disediakan oleh pemerintah. Anggapan tercukupinnya kebutuhan masyrakat sipil oleh masjid berdampak pada lemahnya perbaikan pelayanan publik oleh pemerintah. Ketiga, kebijakan masjid untuk meningkatkan jumlah jamaah dengan memberikan 'insentif' berupa kesempatan berobat gratis, memperoleh bantuan pendidikan dan modal usaha, berpotensi menggantikan tujuan masyarakat dalam beribadah. Orientasi aktivitas religius tergeser oleh manfaat sosial yang ditawarkan oleh masjid Jogokariyan. Dengan demikian perlu adanya evaluasi untuk melepaskan masyarakt dari ambivalensi demikrasi dan tetap menciptakan komunikasi yang efektif oleh masyrakat sipil mellaui ruang-ruang publik yang ada.

\section{DAFTAR RUJUKAN}

Carpentier, Nico. (2008). The Belly of the City: Alternative Communicative City Network dalam International Communication Gazette. P.237-255

Habermas, Jürgen. (1996). Between Facts and Norms: Contributions to a Discourse Theory of Law and Democracy, William Rehg (terj.). Cambridge: MIT Press.
Iqbal, Muhammad. (1971). The Reconstruction of Religious Thought in Islam. Lahore: Asyraf Publication

Prasetyo, Antonius Galih. (2012). Menuju Demokrasi Rasional: Melacak Pemikiran Jürgen Habermas tentang Ruang Publik dalam Jurnal Ilmu Sosial dan Ilmu Politik Volume 16, Nomor 2. Yogyakarta: UGM

Prasetyo, Eko. (2005). Assalamu'alaikum: Islam Itu Agama Perlawanan. Yogyakarta: ResistBook

Prihandono, Bambang K. dan Herawati, F. Anita. (2011). "Urban Communication Audit" Untuk Penguatan Hak Asasi Warga Kota: Studi Kasus di Kota Yogyakarta. Working Papers Volume 3, Nomor 2. Yogyakarta: FISIP Universitas Atma Jaya Yogyakarta.

Soelaiman, M. Munandar. (1998). Dinamika Masyarakat Transisi: Mencari Alternatif Teori Sosiologi dan Arah Perubahan. Yogyakarta: Pustaka Pelajar

Suherman, Eman. (2012). Manajemen Masjid; Kiat Sukses Meningkatkan Kualitas SDM Melalui Optimalisasi Kegiatan Umat Berbasis Pendidikan Berkualitas Unggul. Bandung: Alfabeta 